\title{
Virulence Frequencies in Oat Crown Rust in the United States from 2001 Through 2005
}

\author{
M. L. Carson, United States Department of Agriculture-Agricultural Research Service, Cereal Disease Laboratory, \\ University of Minnesota, St. Paul 55108
}

\begin{abstract}
Carson, M. L. 2008. Virulence frequencies in oat crown rust in the United States from 2001 through 2005. Plant Dis. 92:379-384.

In all, 680 single-pustule isolates of the oat crown rust pathogen, Puccinia coronata f. sp. avenae, were collected from cultivated and wild oat (Avena sativa and A. fatua, respectively) in the major oat-production areas of the United States from 2001 through 2005. They were tested for virulence on seedlings of differential oat lines in the greenhouse. In all, 171 races were found among the 357 isolates from the winter oat region of the United States, whereas 212 races were found among 323 isolates from the spring oat region. The crown rust population derived from winter oat in the southern United States was distinct from the spring oat population in the upper Midwest, although there was no virulence unique to either population. Virulence to $P c 48$ and Pc52 increased significantly in both regions during 2001 to 2005 . Virulence to Pc59 increased and virulence to Pc53 decreased in the winter oat region during the same period. Many of the virulence associations previously reported in the U.S. oat crown rust population in the early 1990 s also were found in both regions in this survey. Associations between virulence to the $P c$ genes were predominately positive in both regions; however, both positive and negative associations occurred more frequently in the winter oat region. Much of the virulence diversity in the oat crown rust population in the United States can be related to the deployment of resistance genes in commercial oat cultivars and virulence associations existing in the oat crown rust population. The mean virulence of the U.S. populations of crown rust continued to increase from 2001 to 2005. Genes for crown rust resistance derived from A. sterilis appear to be rapidly defeated, as has happened to $P c$ genes from A. sativa.
\end{abstract}

Oat crown rust, caused by Puccinia coronata $\mathrm{f}$. sp. avenae, is considered to be the most serious disease of oat (Avena sativa L.) in North America (18). It is distributed worldwide, but is most damaging where heavy nightly dews occur in conjunction with moderate to high temperatures (optimum 21 to $25^{\circ} \mathrm{C}$ ) during the growing season. Under ideal conditions, crown rust can result in complete crop failure. In the United States, the mean estimated loss to crown rust over the 10-year period of 1996 to 2005 was 2.2 and $3.2 \%$ for the upper Midwest (South Dakota, North Dakota, and Minnesota) and the southern plains (Texas and Louisiana), respectively (http://www. ars.usda.gov/Main/docs.htm?docid=10123). Losses in individual years and states were as great as $6 \%$ in the upper Midwest (Minnesota in 1996) and 20\% in the southern plains (Louisiana in 1997).

Corresponding author: M. L. Carson

E-mail: mcarson@umn.edu

Accepted for publication 1 October 2007.

doi:10.1094/PDIS-92-3-0379

This article is in the public domain and not copyrightable. It may be freely reprinted with customary crediting of the source. The American Phytopathological Society, 2008.
The use of host genetic resistance has been the primary means of controlling crown rust of oat. Breeders have relied primarily on race-specific seedling genes that are expressed as some form of hypersensitive reaction. Initially, resistance genes used were found in cultivated hexaploid oat, A. sativa. As these genes were deployed in oat cultivars, corresponding virulence in the crown rust population increased rapidly, to the point that virulence to most of these genes is nearly fixed in the North American population. Later efforts at finding effective resistance turned to exploiting genes found in the wild hexaploid animated oat, A. sterilis, which is the basis of most resistance in current oat cultivars. As these genes have been deployed, corresponding virulence has increased in the crown rust population such that the effective life span of a resistant oat cultivar is often 5 years or less. Breeders and geneticists are now turning to diploid species, particularly black oat, A. strigosa, as sources of new resistance genes; however, introgression of resistance into hexaploid oat is difficult due to differences in ploidy levels and the lack of homology of chromosomes between the two species. The objectives of this study were to characterize and contrast the virulence of the oat crown rust population in the winter and spring oat-growing regions of the United States from 2001 to 2005 and determine the relative effectiveness of known $P c$ genes used in oat improvement programs against the U.S. crown rust population.

Table 1. Source of isolates of Puccinia coronata f. sp. avenae from the United States, 2001 to 2005

\begin{tabular}{|c|c|c|c|c|c|c|}
\hline \multirow[b]{2}{*}{ State } & \multirow[b]{2}{*}{$\operatorname{Area}(1,000 \text { ha })^{a}$} & \multirow[b]{2}{*}{ No. of isolates } & \multicolumn{4}{|c|}{ Source of isolates } \\
\hline & & & Nursery & Field & Avena sativa & A. fatua \\
\hline Alabama & NA & 20 & 20 & 0 & 20 & 0 \\
\hline Florida & NA & 56 & 56 & 0 & 56 & 0 \\
\hline Georgia & 90 & 6 & 6 & 0 & 6 & 0 \\
\hline Illinois & 63 & 6 & 6 & 0 & 6 & 0 \\
\hline Iowa & 248 & 8 & 2 & 6 & 8 & 0 \\
\hline Kansas & 122 & 2 & 2 & 0 & 2 & 0 \\
\hline Louisiana & NA & 35 & 34 & 1 & 32 & 3 \\
\hline Minnesota & 356 & 166 & 107 & 59 & 164 & 2 \\
\hline Mississippi & NA & 1 & 1 & 0 & 1 & 0 \\
\hline Missouri & 42 & 1 & 0 & 1 & 1 & 0 \\
\hline Nebraska & 164 & 14 & 1 & 13 & 14 & 0 \\
\hline New York & 80 & 3 & $\mathrm{NA}^{\mathrm{b}}$ & $\ldots$ & $\ldots$ & $\ldots$ \\
\hline North Carolina & 59 & 11 & 9 & 2 & 11 & 0 \\
\hline North Dakota & 591 & 66 & 36 & 30 & 40 & 26 \\
\hline Oklahoma & 64 & 1 & 0 & 1 & 1 & 0 \\
\hline South Carolina & 48 & 2 & 1 & 1 & 2 & 0 \\
\hline South Dakota & 394 & 26 & 12 & 14 & 23 & 3 \\
\hline Texas & 676 & 223 & 148 & 75 & 185 & 38 \\
\hline Wisconsin & 370 & 33 & 13 & 20 & 33 & 0 \\
\hline Total & $\ldots$ & 680 & 454 & 223 & 605 & 72 \\
\hline
\end{tabular}

${ }^{a}$ Average area planted to oat. Data from National Agricultural Statistics Service, 2000-2004. NA = data not available.

b Aecial isolates from the alternate host, Rhamnus carthartica. 


\section{MATERIALS AND METHODS}

Samples of crown rust-infected leaves were collected from commercial oat fields and oat research nurseries in annual surveys ducted by the United States Department of Agriculture Cereal Disease Laboratory personnel. Survey trips of the major smallgrain-producing regions of the central and eastern United States typically begin in early April in southern Texas and continue until mid- to late July in North Dakota and northern Minnesota. In addition to collecof cereal rusts in the United States con-

tions made on survey trips, samples are received routinely from collaborators throughout the United States, including R. Harrington (Texas), S. Harrison (Louisiana), L. Hall (South Dakota), M. McMullen (North Dakota), H. Kaeppler (Wisconsin), F. Kolb (Illinois), R. Barnett (Florida), and D. Stuthman (Minnesota and Nebraska). In all, 680 single-pustule isolates were derived from samples collected over the 5-year period of the survey (Table 1).

Urediniospores were collected from the samples using a cyclone spore collector

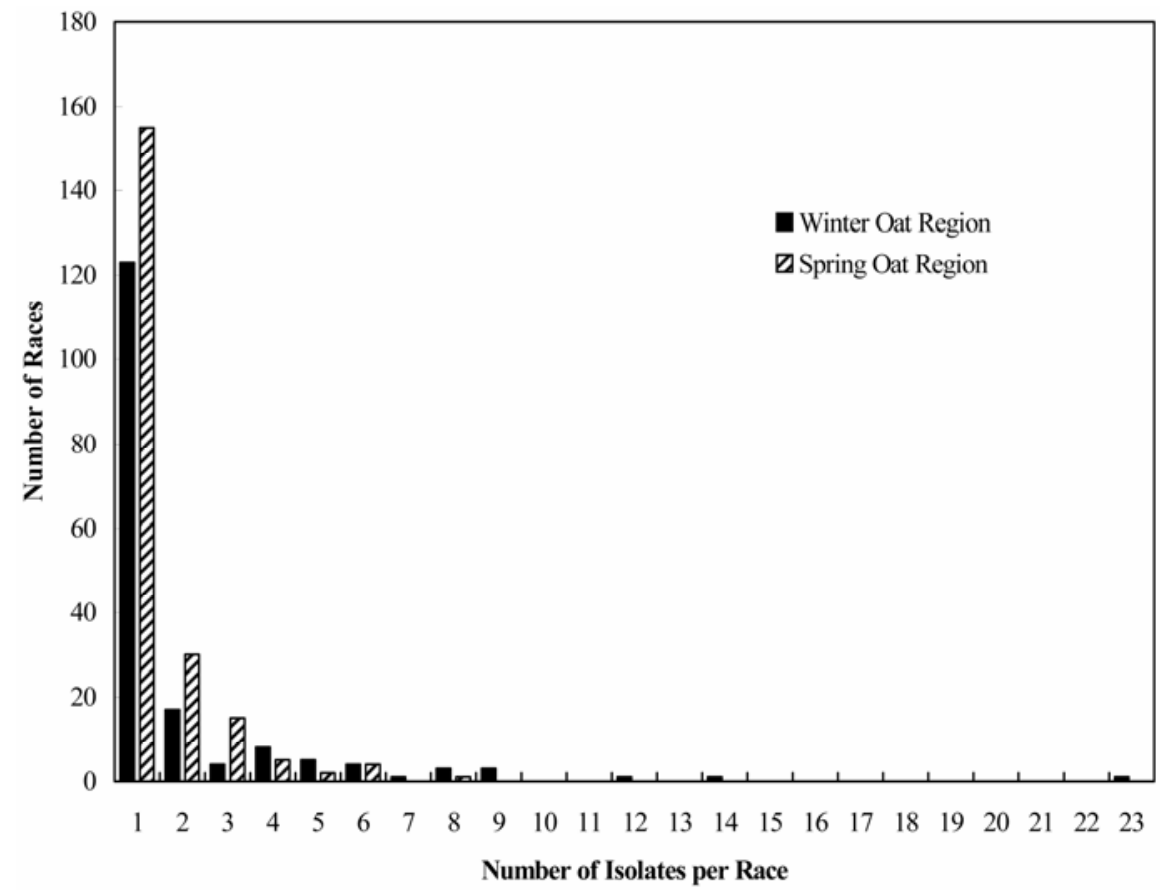

Fig. 1. Number of isolates per race of Puccinia coronata f. sp. avenae from single-uredinial isolates collected in the U.S. winter and spring oat regions from 2001 through 2005. Races were determined using the differential cultivars and nomenclature of Chong et al. (4).

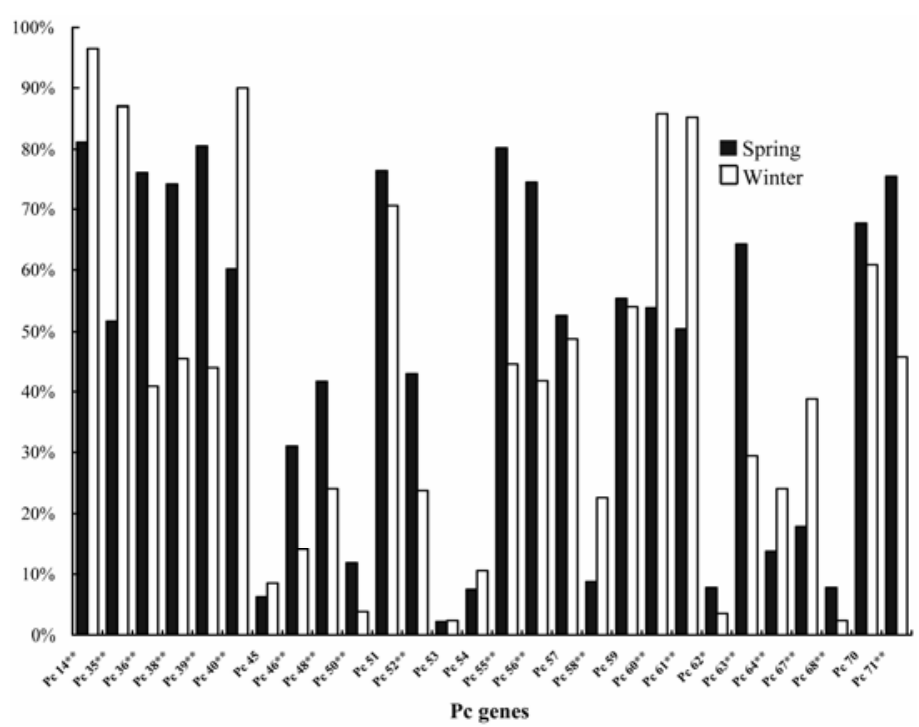

Fig. 2. Virulence frequencies (\%) to 28 oat $P c$ genes in populations of Puccinia coronata f. sp. avenae collected in the winter and spring oat regions of the United States from 2001 through 2005. Asterisks $*$, **, and *** indicate that the difference in virulence frequency in the two oat-production regions of the United States to a given $P c$ gene is significant at the $0.05,0.01$, and 0.001 level of probability, respectively, as determined by Fisher's exact test. and inoculated onto 7- to 9-day-old seedlings of either Marvellous or Starter oat cultivars. Urediniospores were suspended in light mineral oil (Soltrol 70; ConocoPhillips Inc., Houston) and sprayed onto plants. The mineral oil was allowed to evaporate for approximately $30 \mathrm{~min}$ and the plants were placed overnight into a dew chamber at $18^{\circ} \mathrm{C}$. The inoculated seedlings were returned to the greenhouse and, when uredinia appeared, the plants were trimmed to a single uredinium to represent each sample. Seedlings with single uredinia were placed in a dew chamber for 2 to $3 \mathrm{~h}$ to germinate any urediniospores on the leaf surface and then dried to kill any germinated urediniospores. The plants with single uredinia then were placed into isolation cells in the greenhouse to allow the single uredinia to sporulate further. Urediniospores were collected from those single pustules and inoculated onto seedlings of either Marvellous or Starter in isolation cells to increase the single-uredinial cultures. Singleuredinial cultures were kept at $-50^{\circ} \mathrm{C}$ (if not used within 2 weeks of collection) or at $4^{\circ} \mathrm{C}$ at $20 \%$ relative humidity (if used within 2 weeks). Each single-uredinial isolate was tested on a set of 28 differential lines of oat as well as the susceptible control cv. Starter. The differential lines are near-isogenic lines developed at either Iowa State University (Pc14, Pc36, Pc51, $P c 52, P c 53, P c 70$, and $P c 71)$ or AAFC Cereal Research Centre, Winnipeg, Canada (Pc35, Pc38, Pc39, Pc40, Pc45, Pc46, Pc48, Pc50, Pc54, Pc55, Pc56, Pc62, Pc63, Pc64, Pc67, and Pc68). Pc58, Pc59, $P c 60$, and $P c 61$ were represented by cvs. TAM-O-301, TAM-O-312, Coker227, and Coker234, respectively (19). A recent report found that $P c 58$ resistance in TAM-O301 is actually conditioned by three linked loci (7). These $P c$ genes originally were derived from collections of animated oat, A. sterilis, from the Mediterranean region, with the exception of $P c 14$, which came from the A. sativa landrace Ascencao. Three additional differential near-isogenic lines were used to test isolates collected in 2005; Pc91 from A. longiglumis (17), Pc94 from A. strigosa (1), and $P c 96$ from the $A$. sativa (3). Differential lines were grown in vermiculite in $7-\mathrm{cm}^{2}$ pots with 10 to 20 seeds of each of four differential lines planted in each corner of the pot. Seven days after planting, primary leaves of seedlings in each set of differential lines were inoculated with a mineral oil suspension of fresh urediniospores as described previously. Inoculated plants were placed in a dew chamber overnight and moved to a greenhouse bench. Crown rust reactions were measured 12 to 14 days after inoculation. A crown rust reaction of moderately large to large pustules with little or no chlorosis was scored as susceptible; those with flecks or small pustules surrounded by chlorosis or necrosis were scored as resistant. 
The virulence data from isolates obtained from the spring oat region (Minnesota, North and South Dakota, Wisconsin, Iowa, Illinois, Kansas, Nebraska, and New York) were pooled for comparison with isolates from the winter oat region (Texas, Oklahoma, Missouri, Louisiana, Alabama, Florida, Georgia, Mississippi, and North and South Carolina). Races were determined according to the nomenclature of Chong et al. (4) and their frequency calculated within and between each region. Virulence data also were analyzed using Genepop web-based software (http://gene pop.curtin.edu.au/). The frequencies of virulence to each of the 28 differentials in each region were compared using Fisher's exact test. Virulence associations within each region were computed and tested using Fisher's exact test (5). Differences in virulence frequencies also were compared between isolates obtained from wild oat (A. fatua) and cultivated oat (A. sativa), and between isolates obtained from nurseries versus growers' fields within each region. Virulence frequencies within each region also were regressed on years to determine whether significant changes were occurring during 2001 to 2005. Also, the mean virulence of isolates (number of 28 differentials upon which an isolate was virulent) was regressed on year both within each region and with data from both regions combined.

\section{RESULTS}

Races in the United States. In all, 171 races were found among the 357 singleuredinial isolates collected in the winter oat region of the United States. Of these 171 races, $123(71.9 \%)$ were represented by a single isolate, $17(9.9 \%)$ were represented by 2 isolates, $28(16.4 \%)$ were represented by 3 to 9 isolates each, and only 3 races were represented by more than 10 isolates (Fig. 1). One race, LBLB, was represented by 23 isolates. The nine most common races found in the winter oat region, LBLB, LJTB, LQLB, LBLG, LJTL, LBPG, LBMB, LBMG, and LQMB, all share virulence to $P c 40$ and $P c 51$.

Within the spring oat region, 212 races were found among 323 single-uredinial isolates. Of these races, $153(73.1 \%)$ were represented by a single isolate (Fig. 1) and 30 races $(14.2 \%)$ were represented by only two isolates. The most common race from the spring oat region was BQLG, represented by eight isolates. Six of the seven most frequently found races (BQLG, LQLG, LQCG, LQBB, LQMG, and NSRG) were virulent on both $P c 38$ and Pc39.

Combined across both regions, a total of 338 races were found from 2001 through 2005. Of these, only 45 races were found in both regions. Of the 13 most frequent races in common to both regions, 11 were also among the most frequent in one or the other region but not in both. For example, seven of the nine most common races found in the winter oat region (LBLB, LBLG, LBMB, LBMG, LJTB, LQLB, and LQMB) also were found occasionally in the spring oat region and all share virulence to $P c 40$ and $P c 51$.

Population differentiation. The oat crown rust population in the winter oat region was clearly differentiated from the spring oat regional population, although there was no virulence unique to either region. Virulence to $P c 14, P c 35, P c 40$, Pc58, Pc60, Pc61, Pc64, and Pc67 was significantly higher in the winter oat region in 2001 to 2005; virulence to Pc36,
Pc38, Pc39, Pc46, Pc48, Pc50, Pc52, $P c 55, P c 56, P c 62, P c 63, P c 68$, and $P c 71$ was significantly higher in the spring oat region (Fig. 2).

Differences between isolates collected from nurseries versus those from production fields were not significant in the spring oat region (Fig. 3A). In the winter oat region, virulence to $P c 45, P c 50, P c 56$, and $P c 57$ was higher in isolates collected from fields than in nurseries (Fig. 3B). In no instance was virulence to any specific resistance gene significantly higher in isolates from nurseries than those collected from fields.
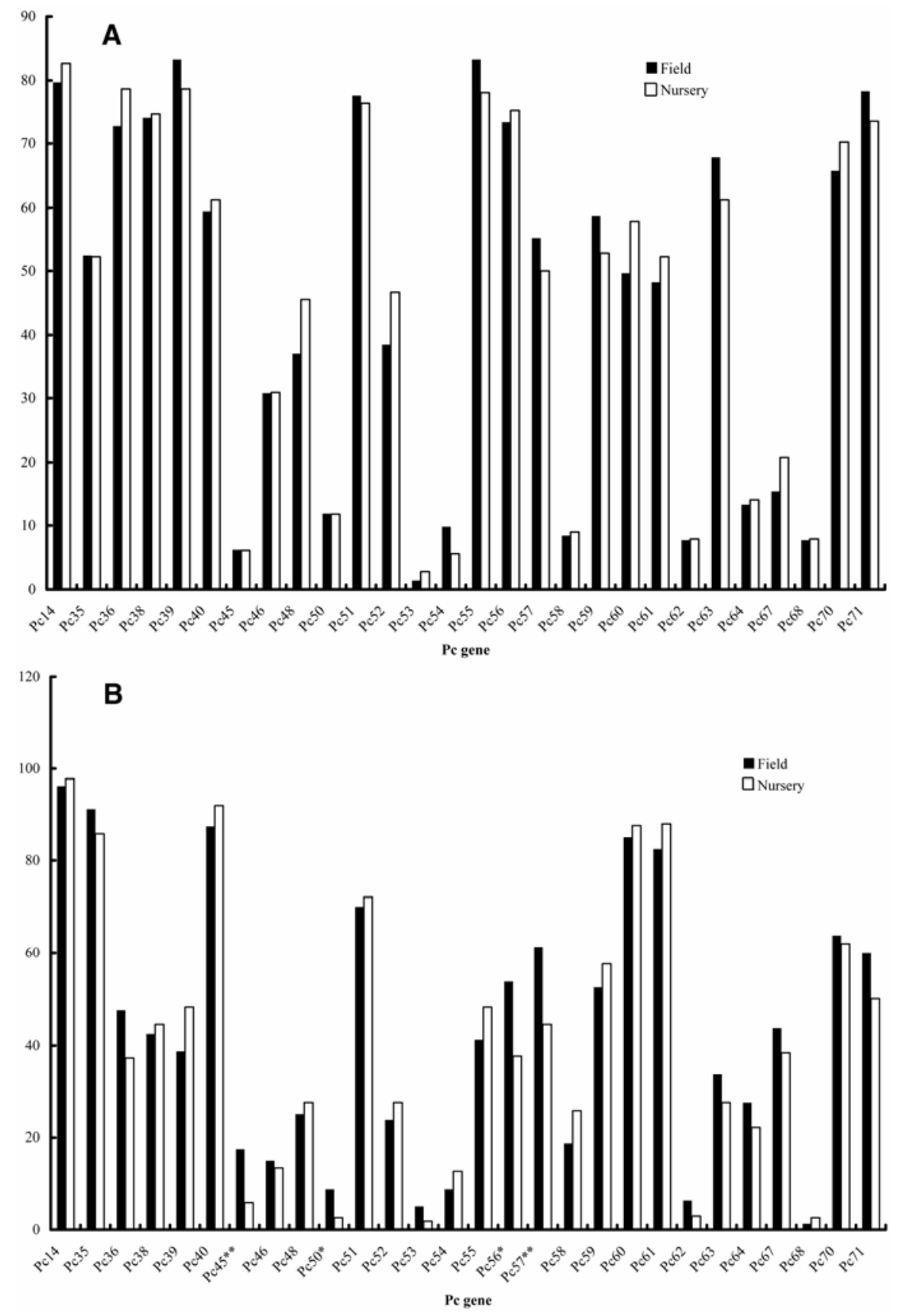

Fig. 3. Virulence frequencies (\%) to 28 oat $P c$ genes in populations of Puccinia coronata f. sp. avenae collected from commercial oat fields and nursery plots in the $\mathbf{A}$, spring and $\mathbf{B}$, winter oat production areas of the United States from 2001 through 2005. Asterisks *, **, and *** indicate that the difference in virulence frequency in collections from the two sources to a given $P c$ gene is significant at the $0.05,0.01$, and 0.001 level of probability, respectively, as determined by Fisher's exact test. 
Isolates collected from wild oat, $A$. fatua, significantly differed from those collected from domesticated oat, A. sativa, in both oat-producing regions of the United States (Fig. 4). In the spring oat region, isolates from A. sativa were significantly more virulent on $P c 36, P c 48$, Pc52, Pc56, Pc57, Pc60, and Pc61 than those from $A$. fatua. In the winter oat region, virulence to $P c 14, P c 39, P c 40, P c 55$, and $P c 71$ was higher on isolates from $A$. sativa, whereas virulence on $P c 45$ was higher on isolates from A. fatua.
Changes in virulence frequency. During 2001 to 2005, virulence to Pc48 and Pc52 significantly increased in both the winter and spring oat regions (Table 2). Virulence to Pc59 significantly increased and virulence to $P c 53$ decreased in the winter oat region during this time period. The virulence of isolates (number of differentials they were virulent on) ranged from 2 to 22 . The mean virulence isolates was 11.5 and 12.3 for the winter and spring oat regions, respectively. The mean virulence of isolates increased in both
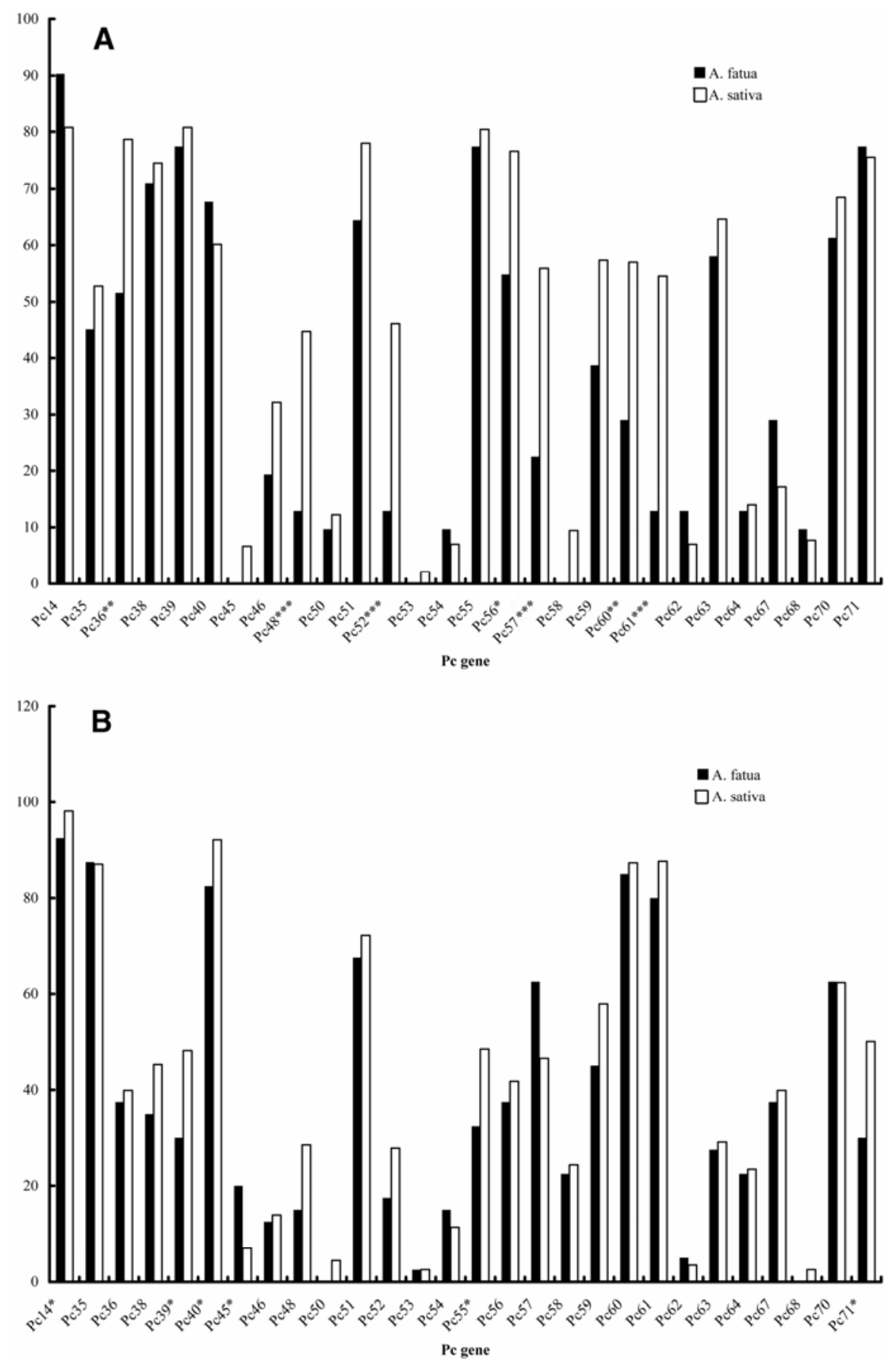

Fig. 4. Virulence frequencies (\%) to 28 oat $P c$ genes in populations of Puccinia coronata f. sp. avenae collected from wild oat (Avena fatua) and domesticated oat (A. sativa) in the $\mathbf{A}$, spring and $\mathbf{B}$, winter oatproduction areas of the United States from 2001 through 2005. Asterisks *, **, and *** indicate that the difference in virulence frequency in collections from the two sources to a given $P c$ gene is significant at the $0.05,0.01$, and 0.001 level of probability, respectively, as determined by Fisher's exact test.

regions from 2001 through 2005, but this increase was significant only if data from both regions were combined (Fig. 5).

Virulence associations. In the winter oat region, $154(41 \%)$ out of 378 possible virulence associations were significant (Table 3). Of these associations, 33 (9\%) were negative. In the spring oat region, 97 (26\%) virulence associations were significant, with $9(2 \%)$ being negative. Sixtythree virulence associations were common to both regions, with all but one being positive. Eight virulence associations were significant, but were of opposite direction, in each region.

Virulence associations observed in this survey generally were consistent with those reported previously by Leonard et al. (12), with some exceptions. The "strong" positive virulence associations in the socalled virulence group 38 of Leonard et al. (12) also were found in both regions in this study. In virulence group 61, the strong association between virulence to $P c 51$ and Pc61 was found in the winter oat region but not the spring. Within the virulence group 58, virulence to $P c 58$ and $P c 59$ were highly associated, but no association between virulence to $P c 35$ and $P c 59$ was found in either oat-growing region during the survey period. Within virulence group 45 , the virulence association between $P c 54$ and $P c 45$ was weakly positive $(P=0.05)$ in the spring oat region but highly $(P=$ $0.001)$ negative in the winter oat region. The persistent virulence associations reported by Leonard et al. $(10,12)$ also were found in this study with the exceptions mentioned above and the additional finding of no significant association between virulence to $P c 63$ and $P c 70$ in the spring oat region.

\section{DISCUSSION}

The oat crown rust population in the United States is highly diverse, regardless of the region of origin of isolates. Greater than $70 \%$ of races found in either the spring or winter oat region consisted of a single isolate collected over the 5 years of the survey. Despite the large number of races found in either region, the two re-

Table 2. Significant changes in virulence frequencies in the oat crown rust (Puccinia coronata $\mathrm{f}$. sp. avenae) populations from the winter and spring oat regions of the United States from 2001 through $2005^{\mathrm{a}}$

\begin{tabular}{lrc}
\hline & \multicolumn{2}{c}{ Region } \\
\cline { 2 - 3 } Pc gene & Winter & Spring \\
\hline Pc48 & $0.086^{*}$ & $0.075^{* *}$ \\
Pc52 & $0.097^{*}$ & $0.093^{* *}$ \\
Pc53 & $-0.023^{*}$ & $\ldots$ \\
Pc59 & $0.066^{*}$ & $\ldots$ \\
\hline
\end{tabular}

a Data are the slopes of the regression of virulence frequency on years of the survey; * and ** indicate that slope is significantly different from zero at the 0.05 and 0.01 level of significance, respectively. 
gions had relatively few races in common, reflecting the differentiation between the two populations. The most frequent race, LBLB, was found 26 times, predominately in the winter oat region, but was isolated 3 times in the northern spring oat region. Five of the six most frequent races found in common between the two regions were found predominately in the winter oat region, with a few isolates found in the spring oat region. This supports the idea that, although crown rust populations in the two regions are distinct, significant movement of isolates between regions

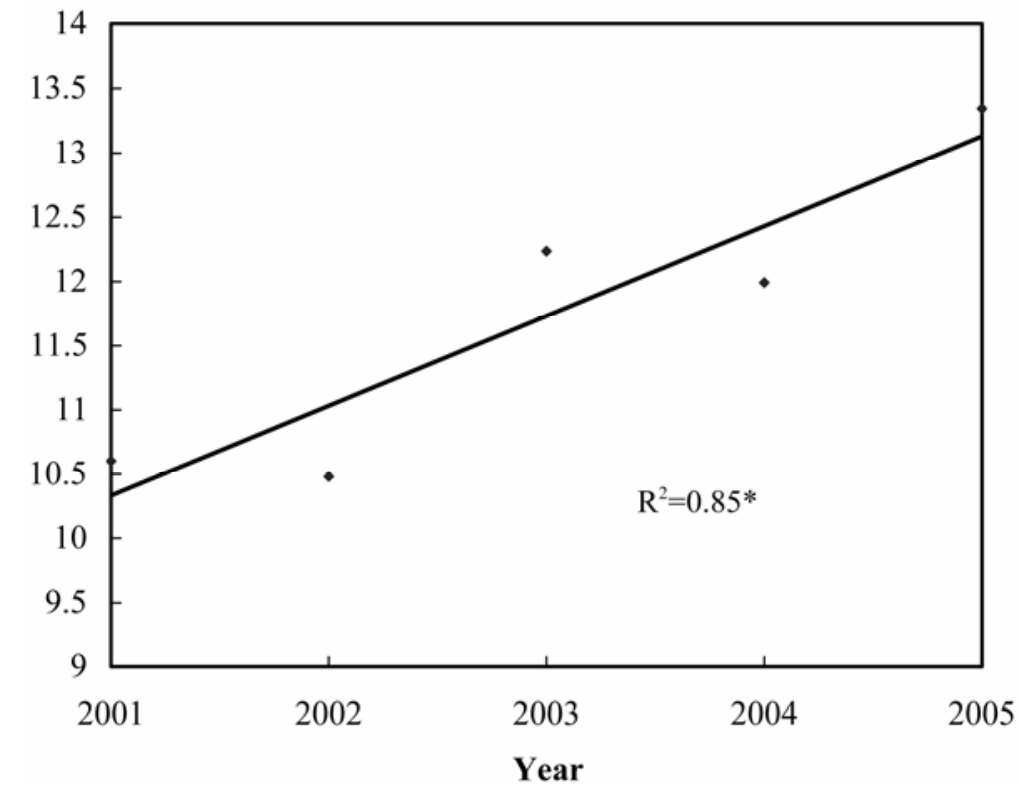

Fig. 5. Change in the mean virulence of single-uredinial isolates of Puccinia coronata f. sp. avenae collected in the United States from 2001 through 2005. Mean virulence is the average number of 28 differential oat lines an isolate is virulent upon. occurs, particularly from the southern winter oat region to the northern spring oat region via the "Puccinia pathway" as occurs with other cereal rusts (18).

Virulence to all of the 28 differential lines was found in both the winter and spring oat regions; there was no virulence unique to either region. However, the crown rust populations in the two major oat-producing areas of the United States were clearly distinct from one another. The frequency of virulence to 21 of the 28 differentials was significantly different between the two regions. Some of these regional differences in virulence frequency clearly reflect the use of corresponding resistance genes in the respective regions. Virulence to $P c 38, P c 39, P c 48$, and Pc68 is significantly higher in the spring oat region, where these genes have been used extensively in oat breeding programs. Similarly, virulence to Pc58,Pc60, and Pc61 was higher in the winter oat region, where these genes were widely used in the Texas A\&M and Coker breeding programs.

The increase in virulence to $P c 48$ during this time period in the spring oat region likely is due to its deployment in numerous spring oat cultivars from 2001 through 2005. Virulence to $P c 48$ increased rapidly in the prairie provinces of Canada when it was deployed in cv. Triple Crown (J. Chong, personal communication). Similarly, the increase in virulence to Pc59 in

Table 3. Associations between virulence to 28 crown rust resistance $(P c)$ genes in the oat crown rust populations in the spring (above the diagonal) and winter (below the diagonal) oat production areas of the U.S. from 2001 through 2005

\begin{tabular}{|c|c|c|c|c|c|c|c|c|c|c|c|c|c|c|c|c|c|c|c|c|c|c|c|c|c|c|c|c|}
\hline & \multicolumn{28}{|c|}{$P c$ gene $^{\mathrm{a}}$} \\
\hline & 14 & 35 & 36 & 38 & 39 & 40 & 45 & 46 & 48 & 50 & 51 & 52 & 53 & 54 & 55 & 56 & 57 & 58 & 59 & 60 & 61 & 62 & 63 & 64 & 67 & 68 & 70 & 71 \\
\hline 14 & - & $* * *$ & $\cdots$ & $\ldots$ & $\ldots$ & $* * *$ & $\ldots$ & $\ldots$ & $\ldots$ & $\ldots$ & $*$ & $\ldots$ & $\ldots$ & $\ldots$ & $\ldots$ & $\ldots$ & $\ldots$ & & & *** & * & $\cdots$ & $\ldots$ & $\ldots$ & $\ldots$ & $\cdots$ & $*$ & $\ldots$ \\
\hline 35 & $* * *$ & - & $\#$ & $\ldots$ & $\ldots$ & $\ldots$ & $\ldots$ & $\ldots$ & $\ldots$ & $\ldots$ & $\ldots$ & $\ldots$ & $\ldots$ & $\ldots$ & $\ldots$ & $\ldots$ & $\ldots$ & $* * *$ & & $\ldots$ & * & $\ldots$ & $\ldots$ & $\ldots$ & $\ldots$ & $\ldots$ & $* * *$ & $\ldots$ \\
\hline 36 & $\ldots$ & $\ldots$ & - & $\ldots$ & $\ldots$ & \#\# & $\ldots$ & $* * *$ & $* * *$ & $\ldots$ & $\ldots$ & $* * *$ & $\ldots$ & $\ldots$ & $\ldots$ & $* * *$ & $*$ & .. & $* *$ & $\ldots$ & $\ldots$ & $\ldots$ & $\cdots$ & $\ldots$ & $\ldots$ & $\ldots$ & . & \\
\hline 38 & $\ldots$ & $\ldots$ & $* *$ & - & $* * *$ & $\ldots$ & $\ldots$ & $*$ & \#\# & $\ldots$ & $\ldots$ & \#\# & $\ldots$ & $\ldots$ & $* * *$ & $\ldots$ & $\ldots$ & * & $\ldots$ & $\ldots$ & $\ldots$ & $\ldots$ & $* * *$ & $\ldots$ & $\ldots$ & $* *$ & * & $* * *$ \\
\hline 39 & & $\ldots$ & $\ldots$ & $* * *$ & - & $\ldots$ & $\ldots$ & $* *$ & $\ldots$ & $\ldots$ & $\ldots$ & $\ldots$ & $\ldots$ & $\ldots$ & $* * *$ & $\ldots$ & $\ldots$ & $\ldots$ & $\ldots$ & $\ldots$ & $\ldots$ & $\ldots$ & $* * *$ & $\ldots$ & $\ldots$ & ** & $* * *$ & $* * *$ \\
\hline 40 & $* * *$ & $* * *$ & $\ldots$ & $\ldots$ & $\ldots$ & - & $\ldots$ & $\ldots$ & $\ldots$ & $\ldots$ & $\ldots$ & $\ldots$ & $\ldots$ & 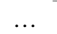 & $\ldots$ & $\ldots$ & $\ldots$ & $\ldots$ & $\ldots$ & $* *$ & $* * *$ & $\ldots$ & $\ldots$ & $\ldots$ & $\ldots$ & $\ldots$ & $\cdots$ & $\ldots$ \\
\hline 45 & \#\#\# & \#\# & . & & 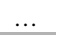 & \#\#\# & - & $\ldots$ & * & $\ldots$ & $\ldots$ & $\ldots$ & $* * *$ & {$[*]$} & $\ldots$ & $\ldots$ & $\ldots$ & $\ldots$ & $\ldots$ & [***] & {$[* *]$} & $\ldots$ & & $\ldots$ & $\ldots$ & $\ldots$ & $\ldots$ & $\ldots$ \\
\hline 46 & $\ldots$ & \#\# & $* * * *$ & $* * *$ & $* * *$ & $\ldots$ & $\ldots$ & - & $\ldots$ & $\ldots$ & $\ldots$ & $\ldots$ & $\ldots$ & $\ldots$ & $* *$ & $* * *$ & $* * *$ & $\ldots$ & $\ldots$ & $* *$ & $\ldots$ & $\ldots$ & $*$ & $\ldots$ & $\ldots$ & $\ldots$ & $\ldots$ & $\ldots$ \\
\hline 48 & $\ldots$ & $\ldots$ & $\ldots$ & $\ldots$ & $* * *$ & $\ldots$ & $\ldots$ & $* *$ & - & $* * *$ & $* * *$ & $* * *$ & $\ldots$ & $\ldots$ & $\ldots$ & $* * *$ & $* *$ & $* * *$ & $* * *$ & * & * & $\ldots$ & [\#\#] & $\ldots$ & $\ldots$ & $\ldots$ & $\ldots$ & [\#\#] \\
\hline 50 & $\ldots$ & $\ldots$ & $\ldots$ & $\ldots$ & * & $\ldots$ & $\ldots$ & $\ldots$ & $* * *$ & - & $\ldots$ & $*$ & $\ldots$ & $\ldots$ & $\ldots$ & $\ldots$ & $\ldots$ & $\ldots$ & $\ldots$ & $\ldots$ & $\ldots$ & $\ldots$ & $\ldots$ & $\ldots$ & $\ldots$ & $\ldots$ & $\ldots$ & $\ldots$ \\
\hline 51 & $\ldots$ & $* * *$ & $\ldots$ & $\ldots$ & $* * *$ & $*$ & \#\#\# & $\ldots$ & $* * *$ & & - & $* * *$ & $\ldots$ & $\ldots$ & $\ldots$ & $\ldots$ & $* *$ & $* *$ & $*$ & $*$ & $\ldots$ & $\ldots$ & $\ldots$ & $\ldots$ & $\ldots$ & $\ldots$ & .. & $\cdots$ \\
\hline 52 & $\ldots$ & $\ldots$ & $\ldots$ & $\ldots$ & $* * *$ & $\ldots$ & $\ldots$ & $* * *$ & $* * *$ & $* * *$ & $* * *$ & - & $\cdots$ & $\ldots$ & $\ldots$ & $* * *$ & $* *$ & $* * *$ & $* * *$ & $*$ & $*$ & $\ldots$ & \# & $\ldots$ & $\ldots$ & $\ldots$ & $\ldots$ & [\#\#] \\
\hline 53 & $\cdots$ & $\ldots$ & $*$ & $\ldots$ & $\ldots$ & $\ldots$ & $\ldots$ & $\ldots$ & $\ldots$ & $\ldots$ & $\ldots$ & $\ldots$ & - & $\ldots$ & $\ldots$ & $\ldots$ & $\ldots$ & $\ldots$ & $\cdots$ & $\ldots$ & $\ldots$ & $\ldots$ & $\cdots$ & $\ldots$ & $\ldots$ & $\ldots$ & & $\cdots$ \\
\hline 54 & \#\# & $\#$ & $\ldots$ & $\ldots$ & & $\ldots$ & {$[\# \# \#]$} & \# & & $\ldots$ & \# & $\ldots$ & $\ldots$ & - & $\ldots$ & $\ldots$ & $\ldots$ & $\ldots$ & 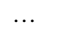 & $\ldots$ & $\ldots$ & $\ldots$ & & $\ldots$ & $\ldots$ & & & \\
\hline 55 & $\ldots$ & $\ldots$ & $\ldots$ & *** & $* * *$ & $\ldots$ & $\ldots$ & $* * *$ & $* * *$ & $*$ & $* * *$ & $* * *$ & $\ldots$ & $\ldots$ & - & $\ldots$ & $\ldots$ & $\ldots$ & $\ldots$ & $\ldots$ & $\ldots$ & $\ldots$ & $* * *$ & $\ldots$ & $\ldots$ & $* *$ & $* * *$ & $* * *$ \\
\hline 56 & $\ldots$ & $\ldots$ & $* * *$ & $*$ & $\ldots$ & $\ldots$ & $\ldots$ & $* * *$ & * & $* *$ & $\ldots$ & * & $*$ & $\ldots$ & $\ldots$ & - & $* *$ & $\ldots$ & $* *$ & $\ldots$ & $\ldots$ & $\ldots$ & $\ldots$ & $\ldots$ & $\ldots$ & $\ldots$ & $\ldots$ & $\ldots$ \\
\hline 57 & $\ldots$ & * & * & $\ldots$ & $\ldots$ & $\ldots$ & $\ldots$ & $* * *$ & $\cdots$ & $\ldots$ & * & $* *$ & $\ldots$ & $\ldots$ & $\ldots$ & $* * *$ & - & * & $* * *$ & $* * * *$ & $* * *$ & $\ldots$ & $\ldots$ & * & $\#$ & $\ldots$ & $\cdots$ & $\ldots$ \\
\hline 58 & $\ldots$ & **** & $\ldots$ & $\ldots$ & $\ldots$ & $\ldots$ & $\ldots$ & $\ldots$ & $* * *$ & $\ldots$ & $*$ & $* * *$ & $\ldots$ & * & $\ldots$ & * & $\ldots$ & - & $* * *$ & * & & $\ldots$ & $\ldots$ & $\ldots$ & $\ldots$ & $\cdots$ & $\cdots$ & $\ldots$ \\
\hline 59 & & & * & & $* * *$ & $\ldots$ & $\ldots$ & $* *$ & $* * *$ & $\ldots$ & $* *$ & $* * *$ & $\ldots$ & $\ldots$ & $* * *$ & $* * *$ & $* * *$ & $* *$ & - & $* * *$ & $* *$ & & 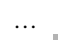 & $\ldots$ & $\ldots$ & $*$ & $\cdots$ & $\ldots$ \\
\hline 60 & $*$ & $* * *$ & $\ldots$ & \#\# & \# & $* * *$ & [\#\#\#] & $\ldots$ & $\ldots$ & $\ldots$ & . & $\ldots$ & $\ldots$ & $\#$ & \#\# & $\ldots$ & $*$ & $* *$ & $\ldots$ & - & $* * *$ & $\ldots$ & $\ldots$ & $*$ & $\ldots$ & $\ldots$ & $\ldots$ & $\ldots$ \\
\hline 61 & $* * *$ & $* * *$ & $\ldots$ & \# & $\ldots$ & $* * *$ & [\#\#\#] & \# & $\ldots$ & \# & $* * *$ & $\ldots$ & $\ldots$ & \#\#\# & $\ldots$ & $\ldots$ & $*$ & $\ldots$ & $\ldots$ & $* * *$ & - & $\ldots$ & $\ldots$ & $* *$ & $\ldots$ & $\ldots$ & $\ldots$ & $\ldots$ \\
\hline 62 & $\ldots$ & $\ldots$ & $* *$ & $\ldots$ & $\ldots$ & $\ldots$ & $\ldots$ & $\ldots$ & $\ldots$ & $\ldots$ & $\ldots$ & $\ldots$ & $\ldots$ & $\ldots$ & $\ldots$ & $\ldots$ & $\ldots$ & $\ldots$ & $\ldots$ & $\ldots$ & $\ldots$ & - & $\ldots$ & $* * *$ & $\ldots$ & $\ldots$ & $\ldots$ & $*$ \\
\hline 63 & $\ldots$ & $\ldots$ & $* *$ & **** & $* * *$ & $\ldots$ & $\ldots$ & $* * *$ & {$[*]$} & $\ldots$ & $* * *$ & $\ldots$ & $\ldots$ & ... & $* * *$ & $\ldots$ & * & \#\# & $* *$ & $* * *$ & \#\#\# & & - & $\ldots$ & $\ldots$ & $* *$ & & $* * *$ \\
\hline 64 & $\ldots$ & $* * *$ & $\ldots$ & $* * *$ & \#\# & $\ldots$ & $\ldots$ & $\ldots$ & $\ldots$ & $\ldots$ & \#\#\# & $\#$ & $\cdots$ & & $\# \#$ & $\ldots$ & $\ldots$ & & $\cdots$ & $* *$ & $*$ & $* * *$ & & - & $\ldots$ & $\ldots$ & {$[*]$} & [*] \\
\hline 67 & $\ldots$ & $\ldots$ & $* *$ & \# & & $\ldots$ & $*$ & $\ldots$ & $\ldots$ & $\ldots$ & $\ldots$ & $\ldots$ & $* *$ & $* *$ & $\cdots$ & $* *$ & $\#$ & $* * *$ & $* *$ & $\ldots$ & \# & $\ldots$ & & \#\#\# & - & $\ldots$ & $\ldots$ & . \\
\hline 08 & 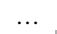 & $\ldots$ & $\ldots$ & * & $* *$ & $\ldots$ & $\ldots$ & $* *$ & $*$ & $\ldots$ & $\ldots$ & $\ldots$ & $\ldots$ & $\ldots$ & $* *$ & $\ldots$ & $\ldots$ & $\ldots$ & $\ldots$ & $\ldots$ & $\cdots$ & $\ldots$ & $* * *$ & ". & $\ldots$ & - & & \\
\hline 70 & $\ldots$ & $* * *$ & $\ldots$ & $* * *$ & $* * *$ & $* *$ & $\ldots$ & $\ldots$ & $* * *$ & $\ldots$ & $* * *$ & $* * *$ & $\ldots$ & $\ldots$ & $* * *$ & $\ldots$ & $\ldots$ & $\ldots$ & **** & $\ldots$ & $\ldots$ & $\ldots$ & $* * *$ & [\#\#\#] & $\ldots$ & $\ldots$ & - & $* * *$ \\
\hline 71 & $\ldots$ & * & $\ldots$ & $* * *$ & $* * *$ & $\ldots$ & $\ldots$ & $* * *$ & {$[* * *]$} & $\ldots$ & $* * *$ & {$[* * *]$} & $\ldots$ & $\ldots$ & $* * *$ & $\ldots$ & * & $\ldots$ & $* * *$ & \# & $\ldots$ & $\ldots$ & $* * *$ & [\#\#\#] & $\ldots$ & $* *$ & $* * *$ & - \\
\hline
\end{tabular}

a $*, * *$, and $* * *$ indicate a positive virulence association between the two genes significant at the $0.05,0.01$, and 0.001 level of probability, respectively, based on Fisher's exact test. Highlighted cells indicate that a significant association was found in both oat production areas. Symbols \#, \#\#, and \#\#\# indicate a negative virulence association between the two genes significant at the $0.05,0.01$, and 0.001 level of probability, respectively, based on Fisher's exact test; brackets indicate that virulence association between the two genes was of opposite direction in the two production areas. 
the winter oat region likely is due its use in the popular cv. Tam-O-312. The significant decrease in virulence to Pc53 in the winter oat region is not easily explained, because this gene has not been used in any cultivars other than some component lines of the Iowa multilines. Virulence to Pc53 has never been common in the United States but was totally absent from the winter oat region in the last 3 years of the survey.

Virulence to Pc68 remains very low in the U.S. crown rust population; however, in the prairie provinces of Canada, virulence to Pc68 is now over $50 \%$ in commercial oat fields (J. Chong, personal communication). Pc68 has been widely used in the prairie provinces of Canada in the oat cvs. AC Assiniboia, Ronald, AC Medallion, and others. Although it may be tempting to recommend the use of $P c 45$ in U.S. oat breeding programs because corresponding virulence is quite low in both the winter and spring oat regions, the frequency of virulence to Pc45 is high in California (9), Mexico (13), Israel (11), South America (14), and South Africa (20), indicating little apparent fitness cost to carrying this unnecessary virulence in the pathogen population. Similarly, virulence to Pc53 is common in Uruguay and Brazil (14), indicating that its effectiveness might not last long if used in U.S. oat cultivars. Virulence to $P c 91$, a resistance gene from Amagalon (A. magna $\times$ A. longiglumis, 17) that is in cv. HiFi from North Dakota State University, was detected at a low level in both the spring and winter oat regions in 2005, the first year this differential was used in the U.S. survey. No virulence was detected for $P c 94$, a new resistance gene from A. strigosa (1) that is in the new Canadian cv. Leggett. Virulence also was found in the spring oat region to $P c 96$, another new gene from $A$. sativa that is being used in the Winnipeg oat-breeding program (3).

Virulence associations, particularly positive ones, were common in the U.S. crown rust population in this study and previous reports $(10,12)$. The higher frequency of associations among virulence in the winter oat region compared with the spring oat region may be due in part to the lack of sexual recombination in the winter oat region because the alternate host buckthorn does not occur there. The presence of many virulence associations in the spring oat region where sexual recombination on buckthorn occurs regularly may be attributed to selection favoring genotypes with paired virulences (10). Even though most of the virulence associations previously reported also were found in this study, there were some exceptions as noted above. These inconsistencies may be the result of the aggregation of isolates over multiple years and over wide geographic areas in this study, resulting in apparent linkage disequilibria (or lack thereof) if frequencies of virulence fluctuated between years or between areas lumped together in the analysis (10).

The continued increase in the mean virulence of the U.S. oat crown rust population in this and a previous report (9) does not bode well for the success of exploiting race-specific seedling genes, either singly or in combination, for crown rust control in oat. $P C$ genes derived from $A$. sterilis appear to be suffering the same fate as those derived from A. sativa, where the frequency of corresponding virulence in the pathogen population is now near fixation. Virulence frequencies to some of the more commonly used $P c$ genes from $A$. sterilis are over $70 \%$ in one or both oatgrowing regions of the United States. Furthermore, there is no apparent fitness cost for isolates carrying virulence to many $P c$ genes (9-12). Also, there do not appear to be any strong, consistent negative associations between virulences that could possibly be exploited by deploying cultivars with the corresponding combination of $P c$ genes $(10,12)$.

The development of durable resistance to crown rust through the use of seedling $P c$ genes remains elusive. There is nothing from previous experience of using $P C$ genes to indicate that future attempts will be any more durable. Oat improvement programs should consider shifting their efforts toward race-non-specific, partial forms of crown rust resistance. This type of resistance has long been recognized in cultivated hexaploid oat $(6,15)$, but it has received little attention in most oat improvement programs in the United States. Difficulties in selecting for this type of resistance in the presence of seedling genes that are effective against most of the crown rust population, its relatively low heritability, its association with late maturity, and the poor agronomic performance of many of the sources of partial resistance may have hindered its use. The highly effective partial resistance in MN841801 (8) recently has been found to be controlled by either two additive genes (2) or seven (four major and three minor) quantitative trait loci (16). The development of molecular markers suitable for markerassisted selection of quantitative trait loci for partial resistance in oat may remove some of the barriers to its use in oat improvement.

\section{LITERATURE CITED}

1. Aung, T., Chong, J., and Leggett, M. 1996. The transfer of crown rust resistance Pc94 from a wild diploid to cultivated hexaploid oat. Pages 167-171 in: Proc. 9th Int. Eur. Mediterr. Cereal Rusts Powdery Mildews Conf. Lunteren, The Netherlands. G. H. J. Kema, R.
E. Niks, and R. A. Daamen, eds. European and Mediterranean Cereal Rust Foundation, Wageningen, The Netherlands.

2. Chong, J., 2000. Inheritance of resistance to two Puccinia coronata isolates in a partial resistant oat line MN841801. Acta Phytopathol. Entomol. Hung. 35:37-40.

3. Chong, J., and Brown, P. D. 1996. Genetics of resistance to Puccinia coronata f. sp. avenae in two Avena sativa accessions. Can. J. Plant Pathol. 18:286-292.

4. Chong, J., Leonard, K. J., and Salmeron, J. J. 2000. A North American system of nomenclature for Puccinia coronata f. sp. avenae. Plant Dis. 84:580-585.

5. Good, P. 2005. Permutation, Parametric, and Bootstrap Tests of Hypotheses, 3rd ed. Springer, New York.

6. Heagle, A. S., and Moore, M. B. 1970. Some effects of moderate adult resistance of oats. Phytopathology 60:461-466.

7. Hoffman, D. L., Chong, J., Jackson, E. W., and Obert, D. E. 2006. Characterization and mapping of a crown rust gene complex (Pc58) in TAM O-301. Crop Sci. 46:2630-2635.

8. Leonard, K. J. 2002. Oat lines with effective adult plant resistance to crown rust. Plant Dis. 86:593-598.

9. Leonard, K. J., 2003. Regional frequencies of virulence in oat crown rust in the United States from 1990 through 2000. Plant Dis. 87:13011310.

10. Leonard, K. J. 2007. Persistent virulence associations in sexual populations of Puccinia coronata. Plant Pathol. 56:35-45.

11. Leonard, K. J., Anikster, Y., and Manisterski, J. 2004. Patterns of virulence in natural populations of Puccinia coronata on wild oat in Israel and in agricultural populations on cultivated oat in the United States. Phytopathology 94:505-514.

12. Leonard, K. J., Anikster, Y., and Manisterski, J. 2005. Virulence associations in oat crown rust. Phytopathology 95:53-61.

13. Leonard, K. J., Huerta-Espino, J., and Salmeron, J. J. 2005. Virulence of oat crown rust in Mexico. Plant Dis. 89:941-948.

14. Leonard, K. J., and Martinelli, J. 2005. Virulence of oat crown rust in Brazil and Uruguay. Plant Dis. 89:802-808.

15. Luke, H. H., Chapman, W. H., and Barnett, R. D. 1972. Horizontal resistance of Red Rustproof oats to crown rust. Phytopathology 62:414-417.

16. Portyanko, V. A., Chen, G., Rines, H. W., Phillips, R. L., Leonard, K. J., Ochocki, G. E., and Stuthman, D. D. 2001. Quantitative trait loci for partial resistance to crown rust, Puccinia coronata, in cultivated oat, Avena sativa L. Theor. Appl. Genet. 111:313-324.

17. Rooney, W. L., Rines, H. W., and Phillips, R. L. 1994. Identification of RFLP markers linked to crown rust resistance genes $P c 91$ and $P c 92$ in oat. Crop Sci. 39:940-944.

18. Simons, M. D. 1985. Crown rust. Pages 131172 in: The Cereal Rusts: Vol. II. Diseases, Distribution, Epidemiology, and Control. A. P. Roelfs and W. R. Bushnell, eds. Academic Press, Orlando, FL.

19. Simons, M. D., Martens, J. W., McKenzie, R. I. H., Nishiyama, L., Sadanaga, K., Sebesta. J. and Thomas, H. 1978. Oats: A Standardized System of Nomenclature for Genes and Chromosomes and Catalog of Genes Governing Characters. U.S. Dep. Agric. Publ. No. 509.

20. van Niekerk, B. D., Pretorius, Z. A., and Boshoff, W. H. P. 2001. Pathogenic variability of Puccinia coronata f. sp. avenae and P. graminis f. sp. avenae on oat in South Africa. Plant Dis. 85:1085-1090. 